\title{
Inhibition of glioma cell growth and tumorigenic potential by CCN3 (NOV)
}

\author{
N Gupta, H Wang, T L McLeod, C C G Naus, S Kyurkchiev, S Advani, J Yu, B Perbal,
} R R Weichselbaum

\begin{abstract}
Aims-To establish whether the ectopic expression of CCN3 (NOV) in glioma cells can interfere with their tumorigenic potential and assess its potential value in molecular medicine.

Methods-Glioma cell lines were used to assess whether differences in the degree of intracellular communication induced by the expression of the gap junction protein connexin $43(\mathrm{Cx} 43)$ is related to the differential expression of CCN3 (NOV). The antiproliferative activity of rat $\mathrm{CCN} 3$ (rCCN3; NOV) in glioma cells, has been assessed both in vitro and in vivo with glioma cell lines expressing different amounts of CCN3 (NOV).

Results-Upon ectopic expression of $\mathrm{Cx} 43$, the growth of $\mathrm{C6}$ glioma cells is decreased. An increase of CCN3 (NOV) expression matches the reduced tumorigenic potential of these transfected cells. The localisation of CCN3 (NOV) is affected by the increased expression of $\mathrm{Cx} 43$ in the $\mathbf{C x}-13$ transfected cells, in which it is detected at areas of cell-cell contact. In a xenograft model, CCN3 (NOV) transfected glioma cells were found to induce tumours to a lesser degree than their parental counterparts, which do not express detectable amounts of CCN3 (NOV). Conclusions-Previous observations had suggested an inverse relation between CCN3 (NOV) expression in glioma cells and their tumorigenicity. These results establish a direct association between the establishment of functional gap junctional intercellular communication and the expression of rCCN3 (NOV). In addition to a negative effect on murine and human cell growth, CCN3 (NOV) has antiproliferative activity on tumour cells in vivo. Thus, the antiproliferative activity of the CCN3 (NOV) protein might involve reorganisation of cellular contacts that play a crucial role in tumorigenesis. The antiproliferative activity of CCN3 (NOV) established in this work sets the stage for the potential use of CCN proteins in molecular oncology. (F Clin Pathol: Mol Pathol 2001;54:293-299)
\end{abstract}

Keywords: NOVH; CCN3; CYR61; CTGF; human glioma; extracellular matrix; connexin 43; gap junctional intercellular communication

The CCN3 (NOV) gene ${ }^{1}$ was originally isolated as a target site for myeloblastosis associated virus in avian nephroblastoma, which is a unique animal model of the Wilms's tumour. ${ }^{2}$
It is a member of the CCN family of genes, ${ }^{3}$ which encode multimodular regulatory secreted proteins reported to play roles in fundamental biological processes, such as cell attachment and proliferation, differentiation, angiogenesis, and development. ${ }^{4-6}$

In addition to the three prototypic founding members (CYR61 (cysteine rich), CTGF (connective tissue growth factor), and NOV (nephroblastoma overexpressed)), three other CCN proteins (WISP1-3 (Wnt induced secreted proteins)) have also been described in humans. ${ }^{7-10}$ Further to a recent nomenclature proposal (First International Workshop on the CCN Family of Genes), these proteins are now designated under the CCN acronym, with numerals corresponding to the chronology of their discovery. Four structural modules sharing partial identity with insulin-like growth factor binding proteins, the Von Willebrand factor type $\mathrm{C}$ repeat, thrombospondin type 1 repeat, and the C-terminal portion of several extracellular growth factors have been recognised in the CCN proteins. ${ }^{3}$ Despite their similar multimodular architecture and conservation of 38 cysteines, the CCN proteins exhibit distinctive biological properties, ${ }^{4-611}$ which might result from different combinatorial events. ${ }^{6}$ Therefore, it appears that the CCN proteins are capable of stimulating or inhibiting cellular growth in normal conditions, depending upon their cellular localisation and time of expression.

The human CCN3 (hCCN3; NOV) protein is widely detected in the developing human embryo, ${ }^{12}$ with an expression pattern partially overlapping that of other CCN family members. ${ }^{4-6}$ The association of hCCN3 (NOV) with the extracellular matrix, ${ }^{12} 13$ and the interaction of hCCN3 (NOV) with fibulin $1 \mathrm{C},{ }^{14}$ both suggest that hCCN3 (NOV) plays a role in cell attachment signalling. The induction of cell quiescence ${ }^{15}$ and cell growth arrest ${ }^{1}$ by chicken CCN3 (NOV) and the stimulatory effects of hCCN3 (NOV) on NIH3T3 cell growth $^{16}$ account for hCCN3 (NOV) expression both in terminally differentiating and actively proliferating cells.

Because hCCN3 (NOV) expression is tightly correlated with the development of the human nervous system, ${ }^{17}$ and hCCN3 (NOV) protein is detected along neuronal axon processes within human kidney, ${ }^{18}$ we questioned whether abnormal expression of this protein might be associated with brain tumour biology. Our previous observations indicated that glioma and astrocytoma cells that expressed the highest 
amounts of CCN3 (NOV) were those exhibiting the least aggressive phenotype,${ }^{19}$ suggesting an inverse relation between tumorigenicity of these tumour cells and CCN3 (NOV) expression, a conclusion consistent with the antiproliferative properties of CCN3 (NOV).

In our present study, we examined whether the expression of the rat $\mathrm{CCN} 3$ ( $\mathrm{rCCN} 3$; NOV) correlated with the degree of cell-cell communication induced by the gap junction protein connexin 43 ( $\mathrm{Cx} 43)$, and investigated the antiproliferative activity of hCCN3 (NOV) in glioma cells, both in vitro and in vivo.

\section{Materials and methods}

DIFFERENTIAL DISPLAY AND SEQUENCING

To identify differentially expressed RNA species, we used the Genomyx Hieroglyph mRNA profile system (Genomyx Corp, San Francisco, California, USA) and the GenomyxLR ${ }^{\mathrm{TM}} \mathrm{DNA}$ sequencer. A $200 \mathrm{ng}$ sample of total RNA was treated with DNAse I (Gibco, Cergy Pontoise, France), and the reverse transcription was performed with 10 different $3^{\prime}$ primers consisting of T7 partial sequence followed by T12 and two anchored bases in different combinations, according to recommended procedures. Reverse transcribed duplicate RNA samples were subjected to polymerase chain reaction (PCR) amplifications using the same anchored 3' primer and different $5^{\prime}$ arbitrary primers and using cold dNTPs, ${ }^{33}$ P-dATP, AmpliTaq DNA polymerase, and PCR buffer containing $15 \mathrm{mM}$ $\mathrm{MgCl}_{2}$. The PCR products were separated on a $4.5 \%$ urea polyacrylamide gel, which was exposed to $x$ ray film and differentially displayed bands selected and excised from the gels. These samples were re-amplified with M13 reverse (24 mer) and T7 primers in a secondary PCR reaction using AmpliTaq gold (Perkin Elmer Cetus, Foster City, California, USA). Some of the resulting products were separated on low melting point agarose gels to produce radiolabelled probes for northern blot analysis, and the remaining reamplified products were treated with alkaline phosphatase and exonuclease I and then bidirectionally sequenced.

ANTIBODIES

CNBrSepharose (Pharmacia, San Quentin en Yvelines, France) was swollen in $10 \mathrm{ml} 1 \mathrm{mM}$ $\mathrm{HCl}$ and washed with $200 \mathrm{ml}$ of the same solution before transfer into $0.8 \times 4 \mathrm{~cm}$ Poly-Prep chromatography columns (BioRad, Marnes la Coquette, France). The volume of the gel in the column was routinely $3.5 \mathrm{ml}$. A total of $3.8 \mathrm{mg} \mathrm{K} 19 \mathrm{M}$ peptide ${ }^{18}$ was dissolved in $5 \mathrm{ml}$ $0.1 \mathrm{M} \mathrm{NaHCO}$ containing $0.5 \mathrm{M} \mathrm{NaCl}$ and mixed with the CNBr gel within the column, by gentle rotation on a spinning wheel for two hours at room temperature.

The column was washed five times with $3 \mathrm{ml}$ of $0.1 \mathrm{M} \mathrm{NaHCO}$ containing $0.5 \mathrm{M} \mathrm{NaCl}$ and with $3 \mathrm{ml}$ of $0.1 \mathrm{M}$ Tris $/ \mathrm{HCl}(\mathrm{pH} \mathrm{8.0)}$. After resuspending the gel in $5 \mathrm{ml}$ of $0.1 \mathrm{M}$ Tris/ $\mathrm{HCl}$ ( $\mathrm{pH}$ 8.0), the column was rotated for 90 minutes at room temperature and washed three times with $5 \mathrm{ml}$ of $0.1 \mathrm{M}$ acetate buffer ( $\mathrm{pH} 4.0$ ), $0.5 \mathrm{M} \mathrm{NaCl} ; 5 \mathrm{ml}$ of $0.1 \mathrm{M}$ Tris/HCl
( $\mathrm{pH} 8.0$ ), $0.5 \mathrm{M} \mathrm{NaCl}$; and $3 \mathrm{ml}$ phosphate buffered saline (PBS; $\mathrm{pH} 7.4$ ).

For purification of the anti-hCCN3 (NOV) antibodies, a $2 \mathrm{ml}$ sample of anti-K19M antiserum (diluted with $1 \mathrm{ml}$ PBS) was used to resuspend the gel and incubated on the rotating wheel for one hour at room temperature. After collecting the flow through, the column was washed twice with $40 \mathrm{ml}$ of PBS. The bound antibodies were eluted with $5 \times 3 \mathrm{ml}$ of $0.2 \mathrm{M}$ glycine ( $\mathrm{pH} 2.7)$ and collected in tubes containing $0.3 \mathrm{ml} 1 \mathrm{M}$ Tris $(\mathrm{pH} 11.0)$.

For desalting, the $3 \mathrm{ml}$ samples of each bound fraction were loaded on to a PD-10 column (Pharmacia). Once the flow through was discarded, the proteins were eluted with $3.5 \mathrm{ml}$ of $0.1 \mathrm{M}$ phosphate buffer ( $\mathrm{pH} 7.0$ ). Purification of IgGs was performed on a HiTrap protein A column (Pharmacia). After washing the column five times with $1 \mathrm{ml}$ of $0.1 \mathrm{M}$ phosphate buffer ( $\mathrm{pH} 7.0$ ), the bound fractions (K19M-AF-BFs) were loaded as $1 \mathrm{ml}$ samples and the column was washed with $5 \times 1 \mathrm{ml}$ PBS. The bound IgGs were eluted with $5 \times 1 \mathrm{ml}$ $0.1 \mathrm{M}$ citric acid ( $\mathrm{pH} 3.0)$ in test tubes containing $0.3 \mathrm{ml} 1 \mathrm{M}$ Tris $(\mathrm{pH} 8.0)$, and their specificity was checked by western blotting. ${ }^{20}$

Rabbit anti-rCCN3 (NOV) polyclonal antibodies have been described previously. ${ }^{21}$

IMMUNOBLOTTING OF CCN3 (NOV) CONTAINED IN CONDITIONED CELL CULTURE MEDIUM

For hCCN3 (NOV) detection, $1 \mathrm{ml}$ fractions of conditioned media were collected from P60 plates with cells growing in monolayer and mixed with $50 \mu \mathrm{l}$ of a $50 \%$ heparin sepharose slurry in PBS. After an overnight incubation at $4^{\circ} \mathrm{C}$ on a rotating wheel the sepharose beads were centrifuged at $23000 \times g$ for 30 seconds, boiled for 10 minutes in sample buffer, and the dissolved proteins were electrophoresed on $15 \%$ Tris/ $\mathrm{HCl}$ precast gels (BioRad), before transfer on to PVDF membranes (Millipore, San Quentin en Yvelines, France). Blots were incubated with affinity purified K19 antiCCN3 (NOV) polyclonal antibody (1/500) for one hour in standard buffer $(1 \times$ Tris buffered saline (TBS), 5\% non-fat dry milk, $0.1 \%$ Tween 20). After washing, the blots were incubated with horseradish peroxidase labelled goat antirabbit IgG (1/5000) (Biorad) for one hour, and detected by enhanced Chemiluminescence (Amersham, les Ulis, France).

\section{CELL CULTURE}

The G59 cells were originally isolated and provided by Dr M Westphal. The G59W540 cells expressing hCCN3 (NOV) were isolated in B Perbal's laboratory. They were stably transfected by means of the pCMV82nov vector. ${ }^{18}$ The rat C6 and human U87-MG glioma cells were cultured under standard conditions. All cells were maintained at $37^{\circ} \mathrm{C}$ in $5 \% \mathrm{CO}_{2}$ using DMEM medium supplemented with $10 \%$ fetal calf serum and $1 \%$ streptomycin and penicillin. Growth curves were performed by plating $5 \times 10^{4}$ cells into tissue culture plates and counting cells with a haemacytometer at the indicated days. The Cx43-13 C6 transfected 


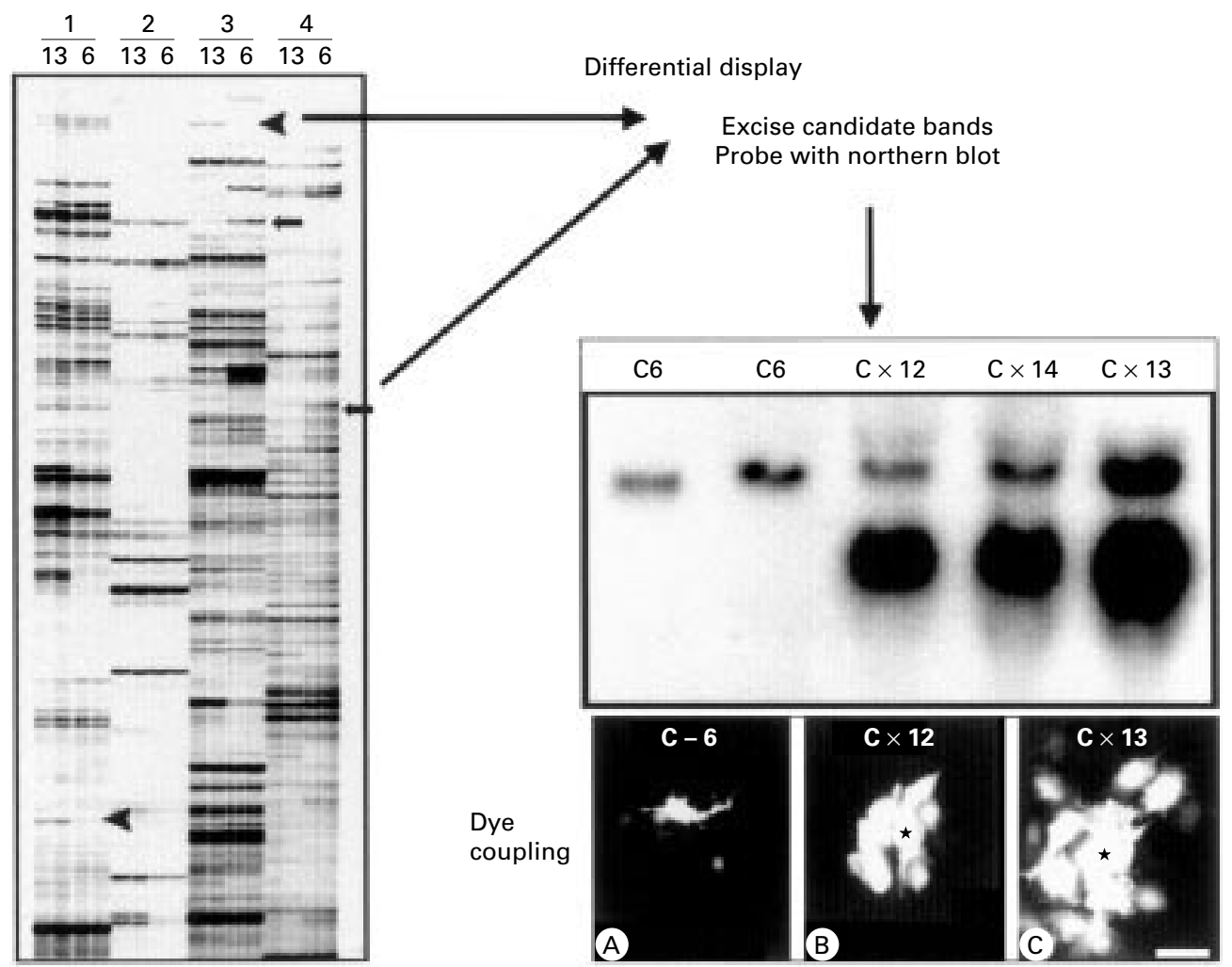

Figure 1 Differential display strategy to identify genes altered in C6 glioma cells transfected with connexin 43 (Cx43). Results for four different sets of primers $(1,2,3$, and 4) are shown, with duplicate lanes in each case for C6 cells (6) and $C x-l 3$ cells (13). Bands were excised from the differential display gel and used as probes on a northern blot containing RNA from C6 cells $\left(C 6, C 6^{L T R}\right)$ and various clones of $C 6$ cells transfected with Cx43 (Cxl2, Cxl4, Cxl3). The degree of Cx43 expression correlates with the level of dye coupling. Arrowheads indicate candidates that are induced by Cx43 expression, whereas arrows show candidates whose expression is reduced in Cx43 expressing cells; modified from Zhu et al. ${ }^{22}$

cells were obtained and maintained as described previously. ${ }^{22}$

\section{ANIMAL STUDIES}

G59W and G59W540 xenografts were grown in the hindlimbs of 6-8 week old athymic female nude mice (Frederick Cancer Research Institute, Frederick, Maryland, USA) by subcutaneous inoculation of $5 \times 10^{6}$ cells suspended in $100 \mathrm{ml}$ PBS. Tumours were allowed to grow for 11-15 days to a mean (SD) volume of $470.3(28.1) \mathrm{mm}^{3}(\mathrm{n}=51)$. At day 0 , initial tumour volume was determined by direct measurement using calipers. Subsequently, tumour volume was determined two to three times each week. Based on the day 0 tumour volume, mice were randomly assigned to treatment groups such that the mean volume of each treatment group was approximately equal. The care and treatment of experimental animals was in accordance with institutional guidelines. Data are reported as per cent of original (day 0) tumour volume and plotted as fractional tumour volume (SEM).

IMMUNOHISTOCHEMISTRY OF VESSELS

Xenografts were surgically resected, snap frozen in OCT compound, and $4 \mu \mathrm{m}$ sections were cut and mounted on poly-L-lysine coated slides. Sections were fixed in $1 \%$ paraformaldehyde (MeOH free) (Polysciences, Warrington, Pennsylvania, USA). After blocking with goat serum, and quenching endogenous peroxidase activity, slides were incubated at $4^{\circ} \mathrm{C}$ overnight with rat antimouse CD31 monoclonal antibody (Pharmingen, San Diego, California, USA), titred to $0.1 \mu \mathrm{g} / \mathrm{ml}$. The sections were incubated for 25 minutes at $37^{\circ} \mathrm{C}$ with rabbit antirat IgG biotinylated secondary antibody $(2 \mu \mathrm{g} / \mathrm{ml})$ (Vector, Burlingame, California, USA), which had been preabsorbed with $1 \%$ normal human serum (Jackson ImmunoResearch, West Grove, Pennsylvania, USA). Appropriate negative controls were performed with rat IgG2a isotype control (Pharmingen), CD31 monoclonal antibody alone, and secondary antibody alone. ABC Vectastain Standard Elite (Vector) was applied and the sections were developed with the Vector DAB kit. Each slide was counterstained with a solution $(0.03 \%)$ of light green SF yellowish (Fisher, Itasca, Illinois, USA). One investigator who was blinded to the treatment groups read the slides. Based on the size of the tumour section, three non-necrotic, high power fields $(\times 400)$ at the tumour periphery were examined using the Nikon Microphot-FX microscope equipped with a Sony digital camera. Vessels were counted using Macintosh Image Pro-Plus software. The mean vessel count was determined for each tumour section.

HISTOPATHOLOGY OF NECROSIS

Sections $(4 \mu \mathrm{m})$ were cut from OCT blocks and mounted on poly-L-lysine coated slides. Sections were fixed in $1 \%$ paraformaldehyde $(\mathrm{MeOH}$ free), stained with haematoxylin and eosin, and examined for total necrosis/tissue 


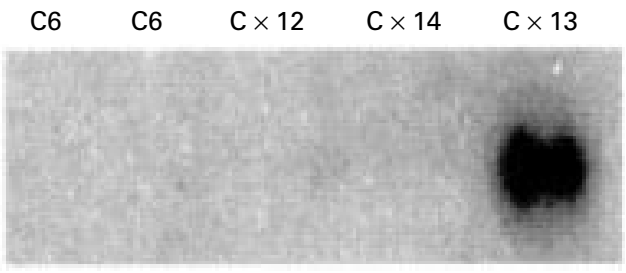

Figure 2 Northern blot analysis of CCN3 (NOV) expression in $C 6$ cells and C6 clones expressing connexin 43 (Cx43). CCN3 (NOV) is only expressed in the Cx-13 clone, which shows the highest expression of Cx43 and the greatest degree of gap junctional coupling.

section. One investigator who was blinded to the treatment groups read the slides. The entire tumour section was scanned $(\times 40)$ and three high power fields were examined for necrosis. The mean per cent necrosis was determined for each tumour section.

\section{Results}

The expression of rCCN3 (NOV) is induced upon gap junctional coupling in rat glioma cells. Rat C6 glioma cells show both decreased concentrations of the gap junction protein $\mathrm{Cx} 43$ and limited intercellular communication. $^{23}$ There is evidence to suggest that reduced cell-cell communication by gap junctions found in cancer cells accounts, in part, for their tumour characteristics. ${ }^{24}$ Several studies have linked aberrant gap junctional intercellular communication (GJIC) in tumours, downregulation of GJIC by cancer causing agents or genes, and upregulation of GJIC by inhibitors of carcinogenesis. ${ }^{24}$ In addition, the introduction and overexpression of connexin cDNAs in tumour cells suppresses the growth and/or tumorigenicity of many transformed cells. We have shown that transfection and expression of $\mathrm{Cx} 43$ in C6 glioma cells suppresses growth. ${ }^{22}$

To determine whether the expression of junctional coupling, we pursued a differential display strategy (fig 1). Changes in gene expression between control rat C6 glioma cells and $\mathrm{C} 6$ cells transfected with $\mathrm{Cx} 43$ were previously detected. ${ }^{25}$ Using this approach, we determined that some members of the CCN gene family were upregulated. We specifically examined rCCN3 (NOV) expression in C6 glioma cells and transfectants. Whereas

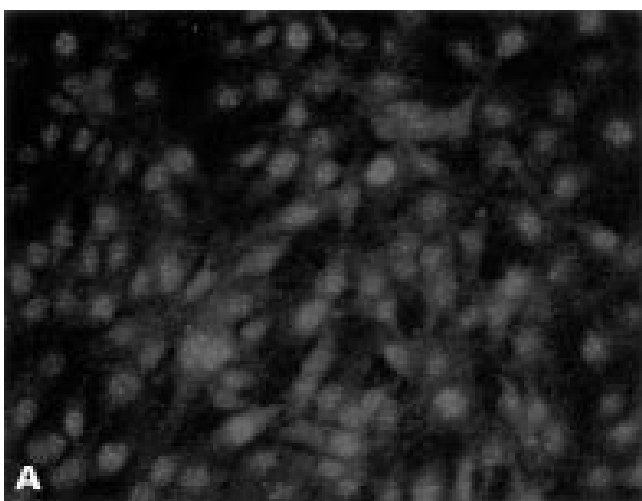
growth control genes could be altered by gap

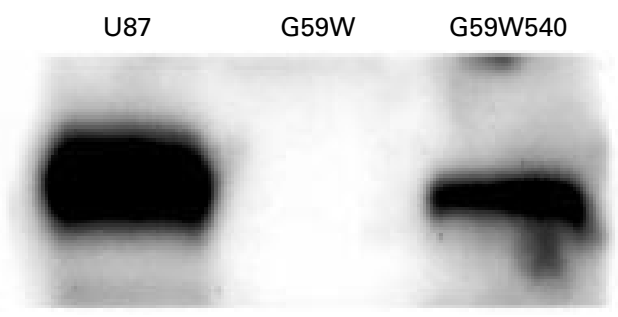

Figure 4 Immunoblot of conditioned medium from glioma cells. Samples $(40 \mu \mathrm{l})$ of heparin-sepharose concentrated conditioned medium from U87, G59W, and G59W540 glioma cells were electrophoresed and blotted. As previously reported, ${ }^{19} \mathrm{G} 59 \mathrm{~W}$ cells do not express detectable amounts of CCN3 (NOV), whereas U87 and G59W540 cells (stably transfected with the pCMV82nov vector) express the full length CCN3 (NOV) protein.

rCCN3 (NOV) mRNA species could not be detected by northern blot analysis in C6 glioma cells, they were readily detected in the $\mathrm{Cx}-13$ cell clone, which expresses high amounts of Cx43 and GJIC (fig 2). Immunocytochemical analysis revealed $\mathrm{rCCN} 3$ (NOV) to be localised in the cytoplasm and at areas of cell-cell contact in the $\mathrm{Cx}-13$ cells. In contrast, non-transfected parental C6 cells displayed only nuclear staining (fig 3).

EXPRESSION OF CCN3 (NOV) IN HUMAN GLIOMA CELLS MODULATES THEIR TUMORIGENIC POTENTIAL

We had established previously that G59W human glioma cells do not express detectable amounts of hCCN3 (NOV) ${ }^{19}$ Because the results obtained in C6 glioma cells (see above) indicated that the expression of CCN3 (NOV) was upregulated under increased gap junctional intercellular communication, we compared the growth properties and tumorigenic potential of G59W and G59W540 cells. Concentrations of secreted hCCN3 (NOV) were confirmed by immunoblotting of conditioned medium obtained from cells (fig 4). Cells expressing hCCN3 (NOV) (G59W540) showed reduced growth when compared with cells not expressing hCCN3 (NOV) (fig 5). This difference occurred during the exponential phase of growth. The calculated doubling time was 18 hours for the parent cell line and 23 hours for the hCCN3 (NOV) expressing cell line (G59W540). Cell lines expressing

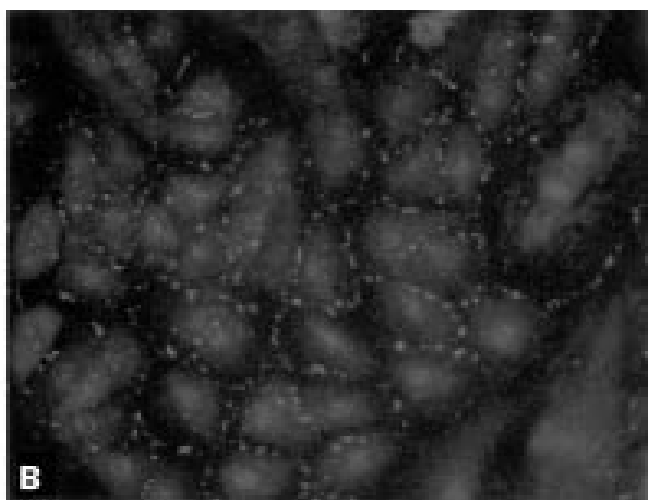

Figure 3 Immunocytochemical analysis of CCN3 (NOV) in (A) C6 cells and (B) Cx-13 cells. C6 cells show nuclear staining, whereas $C x-13$ cells show cytoplasmic staining and localisation of CCN3 (NOV) at areas of cell contact. Original magnification, $\times 250$. 


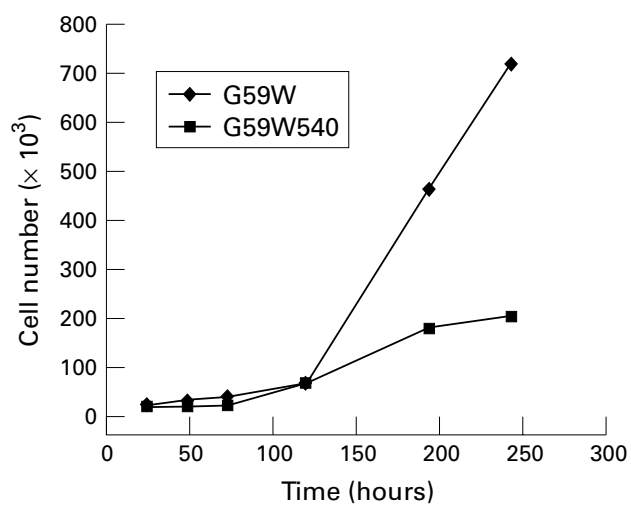

Figure 5 In vitro growth curves of $G 59 W$ and $G 59 W 540$ glioma cells. For the in vitro proliferation assay, 20000 cells from both the G59W and G59W540 cell lines were plated in a six well plate. For each time point, three samples were available for each cell line. Cells were counted at 18 hours, 24 hours, 48 hours, 72 hours, five days, seven days, and nine days.

intermediate amounts of hCCN3 (NOV) showed corresponding intermediate growth levels (data not shown). We studied whether differences in cell cycle distribution would reflect this change in growth but no significant difference in cell cycle ratios was observed (not shown).

hCCN3 (NOV) overexpression in vitro appeared to have a modest effect upon cell growth, therefore we decided to investigate whether its expression affected the growth of tumours in a xenograft model. The growth of tumours in animals requires a host of additional events such as angiogenesis, invasion of host tissues, and interactions with normal surrounding cells. In nude mice bearing G59W tumours, the tumours reached a volume of $250 \mathrm{~mm}^{3}$ after 40 days (fig 6). In comparison, the animals bearing G59W540 tumours (producing hCCN3 (NOV)) failed to demonstrate any visible growth until at least day 20 . Thereafter, tumour growth remained at a plateau, less than $100 \mathrm{~mm}^{3}$, until the end of the study (day 50). The maximal time of tumour growth occurred in G59W cells 30 days after tumour implantation, suggesting that hCCN3 (NOV) inhibits the later development of tumours beyond a threshold size. In addition, $70-80 \%$ of mice injected with cells expressing low amounts of hCCN3 (NOV) developed tumours, whereas only $30 \%$ of mice injected with cells expressing high amounts of hCCN3 (NOV) developed tumours. Immunohistological examination of the excised tumours and measurement of vascular density by CD 31 positive cell counts did not demonstrate an increase in vascularity in the hCCN3 (NOV) expressing tumours (not shown).

\section{Discussion}

Deciphering the molecular basis for the uncontrolled proliferation of cancer cells has been and remains a very promising avenue in oncology research for the development of new treatments.

Normal cell growth and development require a complex network of communication with surrounding cells, the control of which is

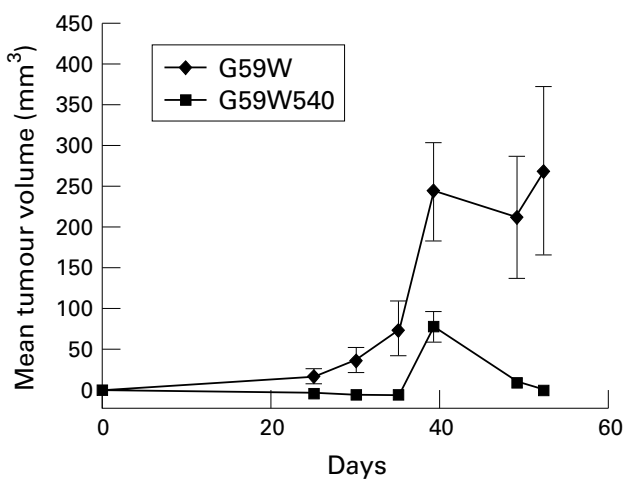

Figure 6 In vivo growth curves of tumours induced by G59W and G59W540 glioma cells. Two complete animal experiments were performed with $G 59 W$ and $G 59 W 540$ cells; $5 \times 10^{6}$ cells were injected into the right hind limb of each mouse with 1/1 medium and metri-gel. Tumour growth was assessed by twice weekly measurements with a caliper; 10 animals were injected in each group. For the G59W cells, all 10 developed tumours. For the G59W540 cells, only three of the 10 animals developed tumours. In each group, the mean size was determined by averaging measurements from the animals that grew tumours. For the second in vivo experiment (data not shown), eight of the 10 animals injected with $\mathrm{G} 59 \mathrm{~W}$ cells grew tumours, but four of these regressed by the final measurement date (day 53). Of the 10 animals injected with G59W540 cells, only four grew tumours, which were all small.

dependent upon many different types of regulatory ligands and proteins. The discovery of the CCN family of secreted cell growth regulators has shed new light on some aspects of cell growth regulation. The CCN1 (CYR61) and CCN2 (CTGF) proteins are positive effectors of epidermal growth factor and transforming growth factor $\beta$, and recent observations indicate that their activity is mediated through interactions with integrins $\alpha v \beta 3, \alpha \operatorname{IIb} \beta 3$, and $\alpha 6 \beta 1{ }^{26-28} \mathrm{CCN} 3$ (NOV) was the first example of a CCN member exhibiting a negative effect on cell growth when ectopically expressed as a full length protein. However, the overexpression of full length CCN3 (NOV) in avian and human tumours is frequently seen, ${ }^{16}$ and the addition of recombinant $\mathrm{CCN} 3$ (NOV) protein to NIH3T3 cells was reported to stimulate their growth. ${ }^{16}$ It therefore appears that the functions of the CCN3 (NOV) proteins might be dependent upon the cellular context in which they are expressed. Similar conclusions could be drawn from results obtained with the CCN4 (ELM1/WISP1) and CCN5 (rCOP1/ WISP2/CTGFL) proteins, ${ }^{6}$ the biological activities of which were found to be cell type dependent. Based on these observations, it was proposed that the spatiotemporal control of CCN protein function might be dependent upon distinct combinatorial events, based on the bioavailability of different interacting partners. ${ }^{6}$

To determine whether the CCN3 (NOV) protein might be useful as a tool in molecular medicine, we have initiated studies aimed at establishing more precisely the biological properties of this protein in tumour cells.

The choice of glioblastomas as a model for studying the antiproliferative potential of CCN3 (NOV) was based upon the initial observation that in glioma and astrocytoma cell lines established from a panel of several human 
tumours, hCCN3 (NOV) expression was inversely correlated with the tumorigenic potential of the cells. ${ }^{19}$ This observation, and the previous results that we obtained suggesting that $\mathrm{CCN} 3$ (NOV) may act as a negative regulator of cell growth, ${ }^{15}$ led us to investigate more thoroughly the relation between CCN3 (NOV) and tumorigenicity.

Our present results establish that in addition to a negative activity on murine and human cell growth, CCN3 (NOV) also has an antiproliferative effect on tumour cells in vivo.

Although many factors contribute to the transformed phenotype, it has been proposed that the increased growth rate of tumour cells is a direct consequence of the reduction of functional gap junctions in these cells. Indeed, the relation between GJIC and growth rate is well documented, ${ }^{24}$ and it appears that loss of GJIC might be crucial in the acquisition of metastatic potential. Our results indicate that there is a relation between the establishment of functional GJIC and the expression of $\mathrm{rCCN} 3$ (NOV), and suggest that the antiproliferative activity of this protein might involve reorganisation of cellular contacts. Immunofluorescence experiments performed with MDCK cells transfected with pCMV82nov revealed that the hCCN3 (NOV) expressed by these cells localised as patches at the surface (G Chevalier et al, 1997, unpublished). Experiments in progress should establish whether there is a direct interdependence between the formation of gap junctions and the expression of CCN3 (NOV).

The mechanism by which CCN3 (NOV) exercises its negative effect upon the growth of tumour cells in vivo remains to be established at the molecular level. Our present results suggest that CCN3 (NOV) interferes with maintenance, rather than establishment, of the tumour state. The late stages in tumour development require increased angiogenesis. Earlier studies indicated that two members of the CCN family, namely murine CCN1 (CYR61) and CCN2 (FISP12), were potent angiogenesis inducers. ${ }^{29} 30$

We have reported previously that hCCN3 (NOV) also interacts with fibulin $1 \mathrm{C},{ }^{14}$ an extracellular protein believed to play a key role in the regulation of cell attachment. The inverse relation that exists between the concentrations of mRNA encoding these two proteins had already suggested that the expression of hCCN3 (NOV) induces, directly or indirectly, the downregulation of fibulin $1 \mathrm{C}$ expression. ${ }^{6}{ }^{14}$ Fibulin 1C itself binds to components of the extracellular matrix such as fibronectin, laminin, nidogen, and fibrinogen. Therefore, it could be hypothesised that CCN3 (NOV) affects the interaction of cells with the extracellular matrix through intermediary molecules, such as fibulin 1C. Thus, hCCN3 (NOV) could represent a class of tumour suppressor gene that negatively regulates events (such as migration) that require cell-cell and cellmatrix interactions, and thereby cell proliferation of anchorage dependent cells. We have reported previously that $\mathrm{CCN} 3$ (NOV) is a marker of differentiation in several tumour types, such as Wilms's tumours and musculoskeletal tumours, ${ }^{6}{ }^{14}$ and a marker of poor prognosis in other tumours, such as renal cell carcinoma $^{31}$ and Ewing's tumours ${ }^{6}$ (Manara et al, 2001, unpublished). Our demonstration that the secreted form of CCN3 (NOV) may suppress tumour growth opens up the possibility of CCN3 (NOV) as a potentially effective anticancer agent.

We thank Professor M Westphal for providing the G59W cells, Dr P Ellis for providing the antirat CCN3 (NOV) antibody, and Dr H Yeger for critical reading of the manuscript. The authors wish to acknowledge Dr B Roizman for support and helpful discussions. M Laurent is acknowledged for technical assistance with cell cultures. These studies were supported in part by grants from the ARC and the Ligue Nationale Contre le Cancer grants from the ARC and the Ligue Nationale Contre le Cancer
(Comités du Cher et de l'Indre) to B Perbal, and the Canadian Institutes of Health Research (MOP-14358) to CC Naus.

1 Joliot V, Martinerie C, Dambrine G, et al. Proviral rearrangements and overexpression of a new cellular gene (nov) in myeloblastosis-associated virus type 1-induced (nov) in myeloblastosis-associated virus type

2 Perbal B. Contribution of MAV-1-induced nephroblastoma to the study of genes involved in human Wilms' tumor development. Crit Rev Oncog 1994;5:589-613.

3 Bork P. The modular architecture of a new family of growth regulators related to connective tissue growth factor. FEBS Lett 1993;327:125-30

4 Lau LF, Lam SC. The CCN family of angiogenic regulators: the connection. Exp Cell Res 1999;248:44-57.

5 Brigstock DR. The connective tissue growth factor/cysteinerich 61/nephroblastoma overexpressed (CCN) family. Endocr Rev 1999;20:189-206.

6 Perbal B. Nov (nephroblastoma overexpressed) and the $\mathrm{CCN}$ family of genes: structural and functional issues. $\mathcal{F}$ Clin Pathol: Mol Pathol 2001;54:57-79.

7 Jay P, Berge-Lefranc JL, Marsollier C, et al. The human growth factor-inducible immediate early gene, CYR61, growth factor-inducible immediate early gene, CYR
maps to chromosome 1p. Oncogene 1997;14:1753-7.

8 Bradham DM, Igarashi A, Potter RL, et al. Connective tissue growth factor: a cysteine-rich mitogen secreted by human vascular endothelial cells is related to the SRCinduced immediate early gene product CEF-10. F Cell Biol 1991;114:1285-94.

9 Martinerie C, Viegas-Péquignot E, Guénard I, et al. Physical mapping of human loci homologous to the chicken nov protooncogene. Oncogene 1992;7:2529-34.

10 Pennica D, Swanson TA, Welsh JW, et al. WISP genes are members of the connective tissue growth factor family that are up-regulated in Wnt-1-transformed cells and aberrantly expressed in human colon tumors. Proc Natl Acad Sci US A 1998;95:14717-22.

11 Ayer-Lelievre C, Brigstock D, Lau L, et al. Report on the first international workshop on the CCN family of genes. $\mathcal{F}$ Clin Pathol: Mol Pathol 2001;54:105-7.

12 Kocialkowski S, Yeger H, Kingdom J, et al. Expression of the human nov gene in first trimester fetal tissues. Anat Embryol 2001;203:417-27

13 Perbal B. Caractérisation et expression du proto-oncogène nov humain dans les tumeurs de Wilms. Bull Cancer (Paris) 994;81:957-61.

14 Perbal B, Martinerie C, Sainson R, et al. The C-terminal domain of the regulatory protein NOVH is sufficient to promote interaction with fibulin 1C: a clue for a role of NOVH in cell-adhesion signaling. Proc Natl Acad Sci US A 1999;96:869-74

15 Scholz G, Martinerie C, Perbal B, et al. Transcriptional down regulation of the nov proto-oncogene in fibroblasts transformed by p60v-src. Mol Cell Biol 1996;16:481-6.

16 Liu C, Liu XJ, Crowe PD, et al. Nephroblastoma overexpressed gene (NOV) codes for a growth factor that induces

17 Su BY, Cai WQ, Zhang CG, et al. A developmental study of novH gene expression in human central nervous system. $C$ $R$ Acad Sci III 1998;321:883-92.

18 Chevalier G, Yeger H, Martinerie C, et al. NovH: differential expression in developing kidney and Wilms' tumors. Am $\mathcal{F}$ Pathol 1998;152:1563-75.

$19 \mathrm{Li}$ WC, Martinerie C, Zumkeller W, et al. Differential expression of novH and CTGF in human glioma cell lines. 7 Clin Pathol: Mol Pathol 1996;49:M91-7.

20 Perbal, B. A practical guide to molecular cloning, 2nd ed. New York: John Wiley \& Sons, 1988.

21 Ellis PD, Chen Q, Barker PJ, et al. The Nov gene encodes an adhesion factor for vascular smooth muscle cells and is dynamically regulated in response to injury. Arterioscler dynamically regulated in response
Thromb Vasc Biol 2000;20:1912-19.

22 Zhu D, Caveney S, Kidder GM, et al. Transfection of C6 glioma cells with connexin 43 cDNA: analysis of expresAcad intercellular coupling, and cell 
23 Naus CC, Bechberger JF, Caveney S, et al. Expression of gap. junction genes in astrocytes and C6 glioma cells. Neurosci Lett 1991;126:33-6.

24 Yamasaki H, Naus CCG. Role of connexin genes in growth control. Carcinogenesis 1996;17:1199-213.

25 Naus CC, Bond SL, Bechberger JF, et al. Identification of genes differentially expressed in C6 glioma cells transfected with connexin 43. Brain Res Brain Res Rev 2000;32:259-66.

26 Grzeszkiewicz TM, Kirschling DJ, Chen N, et al. CYR61 stimulates human skin fibroblast migration through integrin $\alpha \mathrm{v} \beta 5$ beta 5 and enhances mitogenesis through integrin $\alpha \mathrm{v}$ $\beta 3$, independent of its carboxyl-terminal domain. $\mathcal{F} \mathrm{Biol}$ Chem 2001;276:1943-50.

27 Chen N, Chen CC, Lau LF. Adhesion of human skin fibroblasts to Cyr61 is mediated through integrin alpha6 beta1 and cell surface heparan sulfate proteoglycans. $\mathcal{F}$ Biol Chem 2000;275:24953-61.
28 Chen CC, Chen N, Lau LF. The angiogenic factors Cyr61 and connective tissue growth factor induce adhesive signaling in primary human skin fibroblasts. $\mathcal{F}$ Biol Chem 2001;276:10443-52.

29 Babic A, Kireeva M, Kolesnikova T, et al. CYR61, a product of a growth factor inducible immediate early gene, promotes angiogenesis and tumor growth. Proc Natl Acad Sci U S A 1998;95:6355-60.

30 Babic AM, Chen CC, Lau LF. Fisp12/mouse connective tissue growth factor mediates endothelial cell adhesion and migration through integrin $\alpha \mathrm{v} \beta 3$, promotes endothelial cell survival, and induces angiogenesis in vivo. Mol Cell Biol 1999;19:2958-66.

31 Glukhova L, Angevin E, Lavialle C, et al. Specific genomic alterations associated with poor prognosis in high grade renal cell carcinomas. Cancer Genet Cytogenet [In press.]

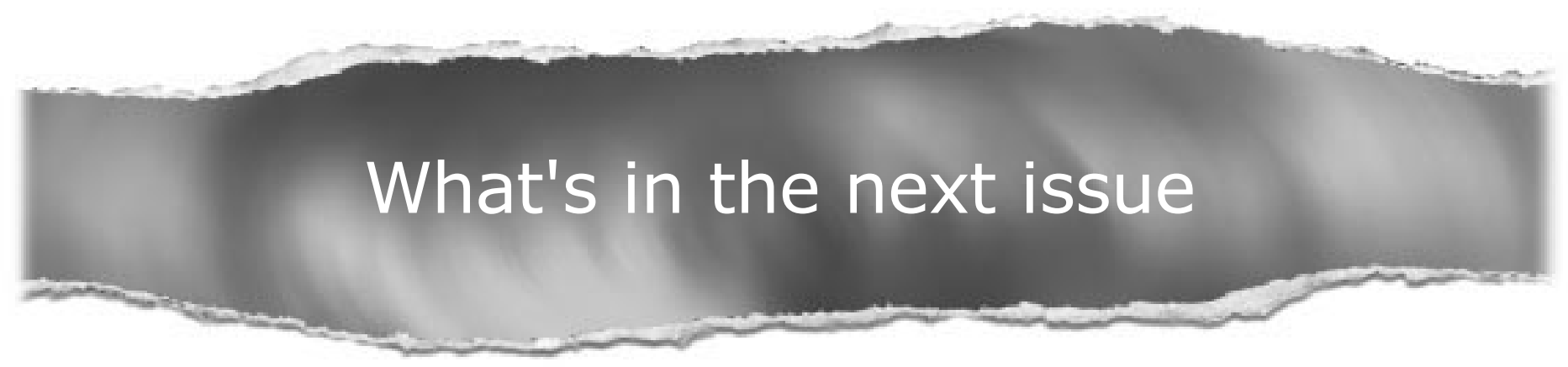

Future content

See which articles have just been accepted for publication and preview the table of contents for the next issue a month before it is published

www.jclinpath.com 